\title{
Understanding Home Math Environments and Math Talks of Children with Low and Middle Socioeconomic Status
}

\author{
İrem Gürgah Oğul* \\ Early Childhood Education Department, İzmir Demokrasi University, İmir, Turkey \\ ORCID: 0000-0002-0419-4776
}

\author{
Yaşare Aktaș Arnas \\ Early Childhood Education Department, Hasan Kalyoncu University, Gaziantep, Turkey \\ ORCID: 0000-0002-0738-9325
}

Article history

Received:

01.06.2021

Received in revised form: 03.01.2022

Accepted:

25.01.2022

Key words:

home learning environment, math skills, parental support, parent-child interaction
The early experiences of children play an important role in their mathematical skills. The purpose of this study is to explore home math environment and math talks of preschool children with low and middle socioeconomic status (SES) in their daily life. The participants of the study consisted of 14 children (45-76 months) with low and middle SES and their parents. The home math environments of the children were examined based on the materials at home and the home math activities with their parents. In addition, the natural conversations of children with their parents were recorded and their math talks were analyzed. The findings showed that the number of materials that support mathematics learning in the children's homes with low SES children is less than children's with middle SES. The homes of children with low and middle SES parents' home math activities diversified in terms of the frequency and the types. In addition, parents and their children produced math talks in various categories such as counting, classification, comparison, ordering, spatial perception, operation, measuring and one-to-one corresponding during daily conversations. In all categories, parent-child dyads with middle SES produced more math talks than those with lowSES. SES is an important factor that should be taken into account in parental support to children's math development.

\section{Introduction}

In the preschool period, the home environment plays an important role in the development of the child's cognitive and academic skills. Early experiences at home before starting primary school play a decisive role in the child's subsequent mathematical skills (Bailey, Siegler \& Geary, 2014). Parents' interaction with their children determines the quality of the environment in which the children live. At this point, the experiences of children from low socioeconomic status (SES) are limited.

\footnotetext{
*Correspondency: iremgurgahogul@gmail.com
} 
The mathematical competencies of primary-school aged children differ from each other at the beginning of the school (Aslan, 2020; Burchinal, McCartney, Steinberg, Crosnoe, Friedman, McLoyd \& Pianta, 2011; Sarama \& Clements, 2009). Children with low SES have less mathematical knowledge than their peers (Aslan, 2013; Klibanoff, Levine, Huttenlocher, Vasilyeva \& Hedges, 2006). It is argued that the disadvantage of children with lower SES in terms of math knowledge is due to the quality of the support parents provide to their children at home (DeFlorio \& Beliakoff, 2015; Melhuish et al., 2008).

The home learning environment provided to their children by parents with different socioeconomic levels is varied (Dearing et al., 2012). Studies (Davis-Kean, 2005; Levine, Suriyakham, Rowe, Huttenlocher, \& Gunderson, 2010; Vandermaas-Peeler, Nelson, Bumpass, \& Sassine, 2009) suggest that families with low SES provide lower quality support for their children's mathematical development. Vandermaas-Peeler et al. (2009) found that families with low SES had less frequent mathematical interactions with their children during reading and playing.

\section{Theoretical background}

Vygotsky (1978) emphasizes in his sociocultural theory that children's interactions with other people facilitate their cognitive development. During interactions, parents provide their children with experiences that support their understanding of math (Tudge \& Doucet, 2004). In the study of Vandermaas-Peeler, Westerberg and Fleishman (2019), they found that parents help their children build meaning and construct information by collaborating with them in daily activities. Parents' formal and informal math activities with children contribute to the development of the children's math skills. Conversations conducted during activities such as counting with children, organizing their toys, and cooking include mathematical concepts (Vandermaas-Peeler, Boomgarden, Finn \& Pittard, 2012).

The home learning environment plays an important role in the development of children's mathematical skills (LeFevre et al., 2009; Mutaf Y1ldı, Sasanguie, De Smedt \& Reynvoet, 2018). However, the mathematical experiences that children are exposed to vary depending on the input provided by their parents at home. In a longitudinal study conducted by Levine et al. (2010), they examined the interactions of between the age of 14 and 30-month-old children and their mothers. They found that the mothers' conversations with their children differed from each other. In addition, it was shown that mothers' conversations involving numbers predict the development of children in cardinal numbers (Levine et al., 2010). Similarly, Ramani, Rowe, Eason, \& Leech (2015) found that the amount of math talks of children aged 3-5 and their parents varied widely even in a study of low-income families.

\section{The current study}

The current study investigated the variety of the home math environments and math talks of children within Turkey. Similar to the results of the studies conducted in the Western countries, studies in Turkey reveal that parental characteristics like parents' educational status and socioeconomic level have a role in children's mathematical skills such as number and operation (Çelik, 2015; Karaman \& İvrendi, 2015). Turkish families moderately support children's mathematical development at home (Ertürk Kara, 2019). In Orçan Kaçan, Yazıcı \& Kandır's (2016) study, almost $10 \%$ of Turkish parents stated that they did not do any math activities with their children, while $40 \%$ stated that they were engaged in math activities at home once or twice a week. However, it was observed that families included in more mathrelated interactions with their children if they were supported (Akıncı Coşkun \& Tezel Şahin, 
2018). Therefore, it is necessary to reveal the quality of the support that families provide to their children at home to develop the home math environment of children.

Although there is an expanding literature on early math talk, the results of many studies are based on self-reports of parents and interviews with parents (DeFlorio \& Beliakoff, 2015; LeFevre, Polyzoi, Skwarchuk, Fast \& Sowinski, 2010). Few studies were designed to directly reflect parent-child interaction (Susperreguy \& Davis-Kean, 2016; Susperreguy, Douglas, Xu, Molina-Rojas, \& LeFevre, 2020). However, studies are needed to shed light on how parents take part in their children's mathematical experiences during daily life. This study provides an overview of the parent-child interaction, which improves the mathematical knowledge of children, takes place in their natural environment.

To understand children's math development, it is crucial to know their home learning environment (DeFlorio \& Beliakoff, 2015). Most of the studies on the home learning environment provide information about the interactions of children with their families in developed countries and Western cultures (LeFevre et al., 2009; Ramani et al., 2015; Sonnenschein, Metzger, \& Thompson, 2016). However, given that the skills that different cultures value and want to transfer to their children are different (Çankaya \& LeFevre, 2016), it becomes important to develop an understanding of parental support living in developing countries. Parenting and family patterns in Turkey are traces of the synthesis of Eastern and Western culture (Kağıtçıbaşı \& Ataca, 2005). At this point, this study will contribute to the intercultural implications in terms of what kind of math inputs parents with low and middle SES living in Turkey provides to their children.

Although many studies to date (DeFlorio \& Beliakoff, 2015; Elliott, Braham, \& Libertus, 2017; Levine, Ratliff, Huttenlocher, \& Cannon, 2012) have indicated that parental math support to the child is affected by socioeconomic factors such as parental education and income level, only a few studies (Gunderson \& Levine, 2011; Levine et al., 2010) have explained the relationship between socioeconomic level and the variation in math talk which the child is exposed to. The current study points to this gap in the studies related to parental math support by focusing on how math talks of children with low and middle SES differ from each other.

The purpose of this study is to explore math environment and math talks of preschool children with low and middle SES in their daily life. The following research questions are answered as follows. (1) How are the home math environments of preschool children with low and middle SES? (2) What kind of math talk emerges during the interaction of preschool children with their parents with low and middle SES? (3) What is the frequency of math talks that emerge during the interaction of the children with their parents?

\section{Methodology}

\section{Research design}

This study, which aims to explore home math environment and math talks of preschool children with low and middle SES with their parents in their daily life, is designed as a case study. Case studies are in-depth explorations of a limited system such as an event, process, or individuals (Creswell, 2012). The case study allows the examination of the situations in real-life contexts, using qualitative and quantitative evidence (Yin, 2014). In this study, children's learning experiences related to mathematics at home were considered as a 
situation, and instruments and voice recordings in the natural environment were used to understand these experiences.

\section{Participants}

Families from low- and middle-income schools were included in this study to explore the mathematical experiences of children from various socioeconomic backgrounds. The study group consisted of 14 children between 45 and 76 months $(M=57$ months $)$ attending three state kindergartens in Adana and their parents. Nine girls and five boys participated in the study. The mothers of 11 children and the fathers of three children participated in the study. In this study, criterion sampling, one of the purposeful sampling methods, was used to explore in depth the math environment and math talks in families with different SES. The purposeful sampling method is useful in explaining situations that are thought to have rich information (Patton, 2002). Parents' income and educational status are among the most important determinants of socioeconomic level (Elliott \& Bachman, 2018). Therefore, while determining the socioeconomic level, monthly income and education level of the family were taken into consideration in this study. Parents' education level and monthly income used to produce a composite SES variable. The demographic characteristics of the participants are presented in detail (see Table 1).

Table 1. Demographic characteristics of the participants

\begin{tabular}{ccc}
\hline Demographic Characteristics & Low SES & Middle SES \\
\cline { 2 - 3 } & $\mathrm{N}$ & $\mathrm{N}$ \\
\hline Maternal Education & 3 & 0 \\
Primary & 3 & 0 \\
Secondary & 1 & 1 \\
High school & 0 & 1 \\
College & 0 & 5 \\
Bachelor's degree & 0 & \multicolumn{2}{c}{5} \\
\hline
\end{tabular}

Paternal Education

$\begin{array}{lll}\text { Primary } & 1 & 0 \\ \text { Secondary } & 2 & 0 \\ \text { High school } & 4 & 0 \\ \text { College } & 0 & 1 \\ \text { Bachelor's degree } & 0 & 6\end{array}$

Number of Children

\begin{tabular}{ccc} 
One & 3 & 2 \\
Two & 3 & 5 \\
Three & 1 & 0 \\
\hline
\end{tabular}

The Child

Has a room 


\begin{tabular}{lcc} 
Does not have a room & 3 & 0 \\
\hline & $\mathrm{M}$ & $\mathrm{M}$ \\
\hline Monthly income (TL) & 1571,43 & 5571,43 \\
\hline
\end{tabular}

\section{Ethical considerations}

This study was approved by the Ethics Committee of the Cukurova University Social Sciences Institute. Before visiting schools, written permissions were obtained from Adana Provincial Directorate of National Education. Afterwards, the parents were interviewed during drop-off or pick-up time and informed about the study. Volunteer parents and their children were included in the study. Informed consent forms were completed by the parents and oral permissions were obtained from the children.

\section{Instruments}

To obtain the data of the study, demographic information form, the Home Math Environment Assessment Tool, Parents' Participation in Mathematics Activities Scale and voice recordings were used to determine home math talk.

\section{Demographic information form}

The demographic information form consists of questions such as the education status of the parents, the monthly income level of the family, the number of children in the family, and whether there is a room for the child at home.

\section{Home math environment assessment tool}

In this study, the Home Math Environment Assessment Tool is developed by the researchers was used to evaluate the math learning environment of children aged three to six years. During the development of the checklist, the literature related to the math learning environment was examined and the items were written. Expert opinions were obtained from six academicians studying in the field of preschool math education and nine preschool teachers. The items were revised according to their opinions. Then, the tool was applied to two parents whose children were in preschool period and their feedback was noted. The content validity of the instrument was tried to be provided by obtaining expert opinion and sample application. There are 45 items which consist of the expressions such as "There are blocks in different colors and/or shapes that my child can use in our house". Parents were asked to check the "yes" box when their child has the specified material and "no" box when they do not.

\section{Parents' participation in mathematics activities scale}

Parents' Participation in Mathematics Activities Scale developed by Gürgah Oğul, Aslan and Aktaş Arnas (2018) was used to determine the mathematical activities of parents with their children. The scale consists of 19 items and three factors: informal math activities (twelve items), operation activities (four items) and measurement activities (three items). Scale items are in four-point Likert type have a value ranked from 1 point (never) to 4 points (6 times or more a week). The internal consistency of the instrument was determined for the factors as $0.89,0.87$ and 0.73 respectively, and for the whole scale as 0.93 . The concurrent validity of the scale was calculated as 0.91 using the İvrendi and Wakefield (2009) scale. Total scores were used in this study. 


\section{Home math talk voice recordings}

Voice recordings were obtained from the parents and their children in order to detect the math talk during their interaction. Voice recorders and lapel microphones were used to obtain math talk that emerged in the natural environment of the participants. Two voice recorders and two lapel microphones were delivered to each parent-child dyad. Parents were asked to record their voices with their children in evening at least for two hours at home. They were free to choose a day to make recordings. Using a coding schema developed by the researchers, the voice recordings were examined to reveal math talks of parent-child dyads.

\section{Data collection}

A face-to-face meeting was conducted with parents who agreed to participate in the study. In this meeting, parents completed the demographic information form and were told how the voice recorder worked. The participants were informed that the purpose was to examine the interaction between parent and child, but not told that it is directly related to math. Thus, the behaviours they will exhibit in daily life and the activities they will perform with their children are not affected by the nature of the study. After the meeting with the parents, the children were interviewed with the parents to give information about the study and introduce the voice recorders. Volunteer parents and children were included in the study.

The conversations of the parents with their children at home were recorded with a voice recorder. In this context, two voice recorders and lapel microphones were delivered to each parent-child dyad, one for the parent and the other for the child. They were asked to put the voice recorder and lapel microphone on at home and record their conversations for at least two hours. The participants were completely released for their activities during the voice recording and no intervention was made. They were told that they could continue to do their daily routines during the recording process. The researchers were not involved in any way during audio recording so that the interaction between the parent and the child would take place naturally. After completing the recording, the participants delivered the devices to the researchers back. After the recording process, parents completed the Home Math Environment Assessment Tool and the Parents' Participation in Mathematics Activities Scale.

\section{Data analysis}

The duration of the voice recordings obtained from the parents ranged from 30 minutes to 4 hours and 29 minutes. The average duration of the voice recordings from the parents was 1 hour and 10 minutes. 30 minutes of recordings from each parent were analyzed. While determining the part to be analyzed, the periods in which the parents and children have the most interaction were taken into consideration.

Voice recordings were transferred to the NVivo 10 qualitative data analysis program and the names of the participants were changed to code names such as Parent 1 (P1) and Child 1 (C1). The conversations of the children and parents were then coded using the content analysis method. In order to ensure reliability in the data analysis, the reliability steps of Compton, Love and Sell (2012) were followed. While analyzing the conversations, first of all the speeches belonging to the parents and children were read once by the researchers and a common coding schema was created. All recordings were encoded in accordance with the specified codes.

In addition, the data obtained from the Home Mathematics Environment Assessment Tool and Parents' Participation in Mathematics Activities Scale was analyzed and reported using 
percentages and frequencies.

\section{Coding of Math Talk}

Within the scope of the study, the recordings obtained in order to reveal the math talk of preschool children with their parents were analyzed. While analyzing the recordings from parents, the studies that investigated the math talk of children with adults (Klibanoff et al., 2006; LeFevre et al., 2009; Ramani et al., 2015; Susperreguy \& Davis-Kean, 2016) were examined and a coding schema were created based on math talk categories. The conversations of the parents and children were separately coded and analyzed by using the coding schema. The expressions used by the participants were coded only if they had mathematical meaning. The expressions used were coded once under the math talk categories. Where an expression refers to more than one category, it was re-coded for all categories that refer to. Only the dialogues between parents and children were analyzed. The participants' conversations with other people at home (such as other parents, siblings, grandparents, and alike) were not analyzed.

\section{Findings}

\section{Home math environment}

In this study, first, the quality of the home math environment that low- and middleSES parents present to their children was examined. The home math environment presented to the children was analyzed based on two components: the materials that support mathematics learning of children in their homes and the math activities of children with their parents in daily life. Table 2 presents the findings about the number of the materials that support mathematics learning in the children's homes with low and middle SES.

Table 2. Number of the materials supporting low- and middle-SES children's math learning

\begin{tabular}{lllll}
\hline & \multicolumn{4}{l}{ Number of the Materials } \\
& Min & Max & M & SD \\
\hline Low SES & 11 & 42 & 24,72 & 12,22 \\
Middle SES & 13 & 36 & 27,29 & 9,41 \\
\hline
\end{tabular}

Table 2 shows that the average number of materials $(\mathrm{M}=27.29 ; \mathrm{SD}=9.41)$ that children from middle SES have at home to support mathematics learning is higher than the average number of materials $(\mathrm{M}=24.72 ; \mathrm{SD}=12.22)$ that children from low $\mathrm{SES}$ have.

The data obtained from the assessment tool showed that all children had legos and wall / table clocks in their homes. In most children's homes, there are materials such as puzzles (13 children), reassembled toys (13 children), balls with different colors and/or sizes (13 children), toy phone (13 children), blocks with different colors and/or shapes (12 children), toys of different animals (12 children), various toy vehicles (12 children), play dough (12 children), dough molds with different shapes (12 children). On the other hand, very few of the children have abacus ( 5 children), a story book with mathematical concepts ( 5 children), a carpet with numbers ( 5 children), an enclosed area for playing (play house) (4 children), toys which can be rotated and attached together (4 children), hourglass ( 4 children), nursery rhymes / finger games / riddle CDs ( 4 children), building toys ( 2 children) and stacking tower toys (Hanoi tower) ( 2 children). It was also found that no child had a toy scales and darts in 
his/her home.

Another component of the children's home mathematics environment was the participation of parents in home math activities. The activities of the parents with their children in daily life were examined. Findings regarding the frequency of parents' participation in math activities at home are presented in Table 3.

Table 3. Participation of parents with low and middle SES in home math activities

\begin{tabular}{lllll}
\hline \multicolumn{5}{c}{ Parents' Participation in Home Math Activities } \\
& Min & Max & M & SD \\
\hline Low SES & 50 & 88 & 64,00 & 13,90 \\
Middle SES & 58 & 80 & 66,29 & 8,51 \\
\hline
\end{tabular}

As Table 2 shows, the middle-SES parents' the average score $(\mathrm{M}=66.29 ; \mathrm{SD}=8.51)$ from the participation in mathematics activities scale is higher from the average score of the parents with low SES $(M=64 ; S D=13.90)$. It was found that mothers and fathers from the middle SES carried out more mathematical activities with their children in daily life than those from lower SES.

When the responses of the parents with low and middle SES to the participation in math activities scale were analyzed, it was found that the parents engaged in math activities with their children on average once or twice a week or three or five times a week. Specifically, parents with low SES reported that they frequently talk to their children about what they do during the day by using expressions such as "morning", "noon", "evening" $(\mathrm{M}=3.86$; SD = $0.38)$ and ask the child to order the numbers from 1 to 10 and from 10 to $1(\mathrm{M}=3.85 ; \mathrm{SD}=$ 0.38). On the other hand, parents with middle SES indicated that they always talk to their children about what they do during the day by using expressions such as "morning", "noon", "evening" $(\mathrm{M}=4.00 ; \mathrm{SD}=0)$ and encourage their children to use the words "yesterday", "today", "tomorrow" $(\mathrm{M}=4.00 ; \mathrm{SD}=0)$.

On the contrary, it was determined that the parents with low SES rarely study on math concepts by using math books $(\mathrm{M}=2.00 ; \mathrm{SD}=1.30)$, and work with their child to cover objects with different sizes using various paper or fabrics and talk about the areas of objects during these activities $(\mathrm{M}=2.14 ; \mathrm{SD}=1.46)$. Also, it was found that parents with middle SES rarely work with their child to cover objects with different sizes using various paper or fabrics and talk about the areas of objects during these activities $(\mathrm{M}=1.86 ; \mathrm{SD}=0.90)$, and play games with their children to fill and empty materials such as water and sand in different sizes and asked questions about how much sand or water the containers took during these games $(\mathrm{M}=$ 2.29; $\mathrm{SD}=0.95$ ).

\section{Math talks during interactions with parents and children}

The second purpose of this study was to determine the types of math talks that preschool children have during their interaction with their parents at home. The voice recordings were analyzed, and math talk that occurred during the interaction of children with their parents was determined. As a result of the analysis, it was found that parents and children with low and middle SES used expressions for many math skills during their interaction at home. Table 4 presents examples of mathematical expressions used by parents and children. 
Table 4. Mathematical expressions used by parents and children with low and middle SES

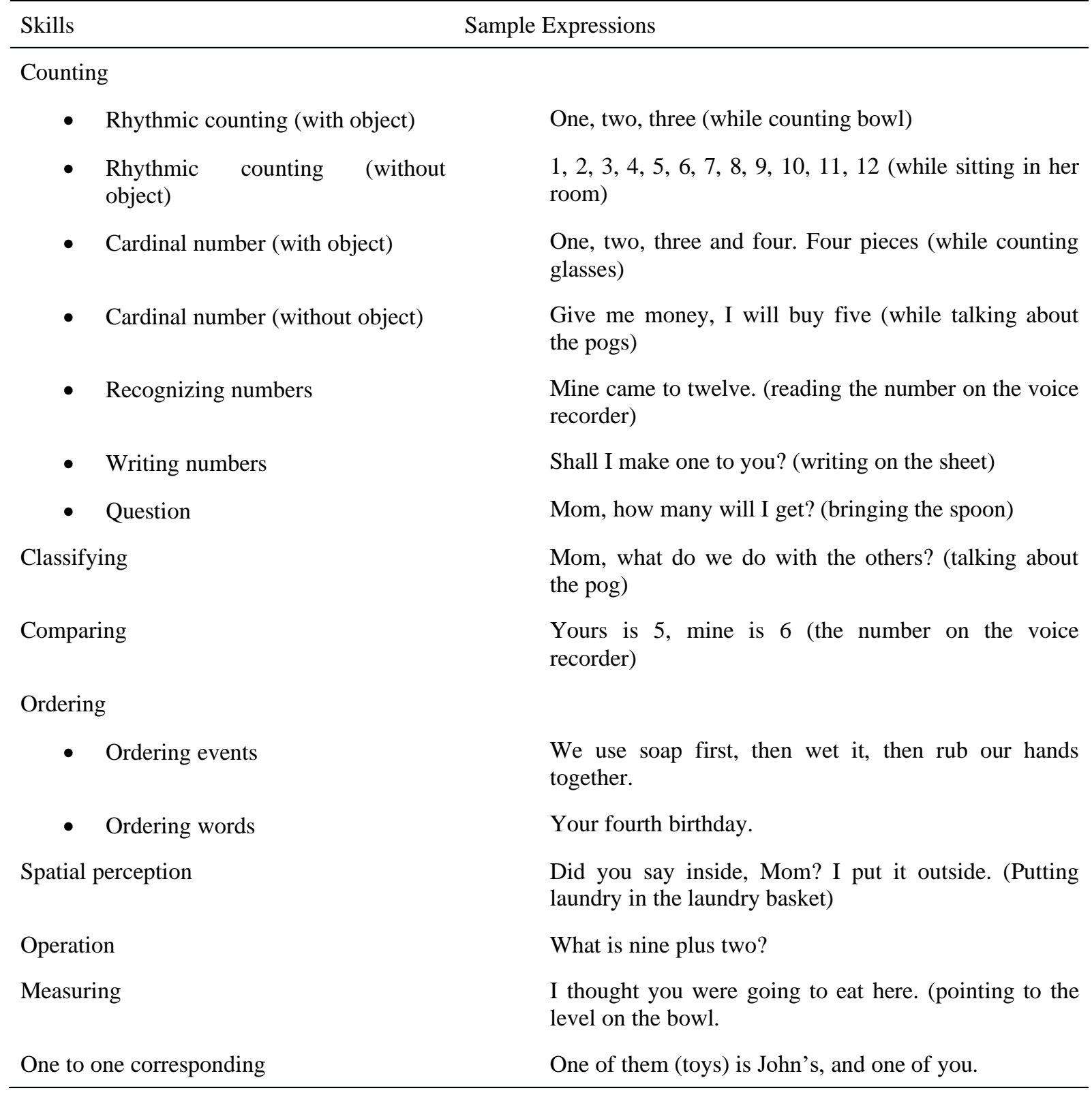

In Table 4, the mathematical expressions used by parents and children during daily life are presented under eight main titles: counting, classifying, comparing, ordering, spatial perception, operations, measuring and one to one correspondence. It was determined that parent-child dyads from both low and middle SES produced math talks in all categories. Specifically, during the interaction of the parents and children, it was revealed that they make conversations about counting such as rhythmic counting, cardinal number, recognizing numbers, writing numbers, and counting questions.

At the same time, they made conversations that require classification of objects in daily life and comparison of two objects or situations according to a particular feature. In these interactions, both parents and children used the words "first", "after" to talk about the sequence of events and used ordering words such as "first" and "second". In a dialogue between Parent 6 and her child below, the mother talked about the sequence of events:

C6: What was his name? 
P6: My princess, my princess. Now you're going to brush your teeth, and after you brush your teeth, I'll dress my princess. I'll take her to the school. (ordering events)

In addition, it has been found that parents and children use words that require spatial perception such as "beside" and "in front of" during their dialogue. For example, Parent 5 used expressions of spatial perception when eating with her child:

C5: Put too much.

P5: Yogurt next to it? (spatial perception)

C5: Uh uh.

P5: Not on it, but next to it. In the bowl. (spatial perception)

C5: In the bowl.

Parents gave place to words related to operations such as addition, subtraction, and division, while children talked about only addition and division. Moreover, it was found that parents and children used words related to measurement such as volume, length, time, and one to one correspondence. To illustrate, during a dialogue between Parent 11 while playing with her children, they talked about their ability to count and one to one corresponding:

P11: Two. Should we give one of this to Alex? You play together. One is yours; one is Alex's (cardinal number) (cardinal number) (one to one correspondence)

C11: Yes. But mine is purple.

P11: Alex takes the other one. You don't have to have two, do you, honey? (cardinal number)

C11: Yes

P11: You don't need two of the same toy. (cardinal number)

In another example given below, parent 5 and her child used words related to measuring and operation while cooking pudding:

P5: Half teaspoon says. That means we're going to put a little bit. Now that we've done half measure, we're going to put in a quarter teaspoon. Is it a quarter? (measuring) (division)

C5: Shall I mix it?

\section{Frequency of math talk during interactions with parents and children}

In order to address the third research question of the study, how often math talk emerges when preschool children interact with their parents was examined. The expressions of the parents and children were coded according to mathematical talk categories and the frequency of these expressions was determined. The frequency of math talk in the dialogues of children and parents is presented in Table 5. 
Table 5 Frequency of math talks during interactions parents and children with low and middle SES

\begin{tabular}{|c|c|c|c|c|c|c|}
\hline \multirow{3}{*}{ Math Talk Categories } & \multicolumn{2}{|c|}{ Low SES } & \multicolumn{2}{|c|}{ Middle SES } & \multicolumn{2}{|l|}{ Total } \\
\hline & Child & Parent & Child & Parent & Child & Parent \\
\hline & $\mathrm{f}$ & $\mathrm{f}$ & $\mathrm{f}$ & $\mathrm{f}$ & $\mathrm{f}$ & $\mathrm{f}$ \\
\hline Counting & 20 & 12 & 37 & 28 & 57 & 40 \\
\hline - Rhythmic counting (with object) & 2 & 0 & 3 & 0 & 5 & 0 \\
\hline - Rhythmic counting (without object) & 3 & 2 & 3 & 0 & 6 & 2 \\
\hline - Cardinal number (with object) & 2 & 1 & 8 & 3 & 10 & 4 \\
\hline - Cardinal number (without object) & 6 & 7 & 22 & 19 & 28 & 26 \\
\hline - Recognizing numbers & 5 & 0 & 0 & 0 & 5 & 0 \\
\hline - Writing numbers & 1 & 0 & 0 & 0 & 1 & 0 \\
\hline - Question & 1 & 2 & 1 & 6 & 2 & 8 \\
\hline Classifying & 0 & 2 & 6 & 2 & 6 & 4 \\
\hline Comparing & 3 & 7 & 10 & 9 & 13 & 16 \\
\hline Ordering & 3 & 9 & 10 & 11 & 13 & 20 \\
\hline - Ordering events & 3 & 5 & 9 & 9 & 12 & 14 \\
\hline - $\quad$ Ordering words & 0 & 4 & 1 & 2 & 1 & 6 \\
\hline Spatial perception & 14 & 7 & 15 & 16 & 29 & 23 \\
\hline Operation & 7 & 7 & 7 & 11 & 14 & 18 \\
\hline - Addition & 7 & 5 & 4 & 6 & 11 & 11 \\
\hline - Subtraction & 0 & 1 & 0 & 0 & 0 & 1 \\
\hline - Division & 0 & 1 & 3 & 5 & 3 & 6 \\
\hline Measuring & 21 & 18 & 33 & 51 & 54 & 69 \\
\hline - Volume & 0 & 0 & 5 & 3 & 5 & 3 \\
\hline - Length & 1 & 2 & 2 & 4 & 3 & 6 \\
\hline - Amount & 9 & 3 & 7 & 11 & 16 & 14 \\
\hline - $\quad$ Time & 11 & 13 & 19 & 32 & 30 & 45 \\
\hline - Question & 0 & 0 & 0 & 1 & 0 & 1 \\
\hline One to one corresponding & 2 & 0 & 0 & 2 & 2 & 2 \\
\hline Total & 70 & 62 & 118 & 130 & 188 & 192 \\
\hline
\end{tabular}

As presented in Table 5, in all categories, it was found that parents with middle SES used mathematical expressions (130 mathematical expressions) more frequently than low-SES parents (62 mathematical expressions). Similarly, children with middle SES used mathematical expressions (118 mathematical expressions) more frequently than children with 
low SES (70 mathematical expressions) in all categories except the one-to-one corresponding category.

The results showed that all parents use 192 mathematical expressions in total in the conversations with their children while the number of mathematical expressions used by the children during these conversations is 188 . The number of the mathematical expressions of the parents and children were close to each other. In addition, when the frequency of the math talk categories used by the participants was ranked from the most frequent to the lowest, it was found that the orders of the categories of children and parents were parallel to each other.

The most common categories that children and parents produced math talk are counting (children 57; parents 40), measuring (children 54; parents 69) and spatial perception (children 29; parents 23). On the contrary, children and their parents gave less space to math talk related to operations (children 14; parents 18), ordering (children 13; parents 20), comparing (children 13; parents 16), classifying (children 6; parents 4) and one-to-one corresponding (children 2; parents 2).

\section{Discussion}

This study was conducted to examine the home mathematics environment and the math talks of children with low and middle SES that occur during the interaction of children with their parents. Important findings obtained from the current study contribute to the growing literature about the quality of the home math experiences that parents from different SES present to their preschool children.

First, it was aimed to reveal the home math environment of low- and middle-SES children. The findings showed that children with middle SES not only had more math learning materials but also participated in more math activities with their parents than children with low SES. This finding showed that all parents in this study provide their children with an environment that supports their learning; however, children with middle SES have an advantage over children with low SES in terms of home mathematics environment. Research shows that growth in a cognitively supportive environment is a determining factor for children's academic achievement in both the short and long term (Altındağ Kumaş, 2020; Crosnoe, Leventhal, Wirth, Pierce \& Pianta, 2010). In this sense, young children need an encouraging and supportive environment for their development (McCartney \& Phillips, 2006). However, studies (Bjorklund, Hubertz \& Rubens, 2004; Ramani et al., 2015; Vandermaas-Peeler et al., 2009) suggest that the mathematical experiences of children differ according to the materials they have. For example, Ramani et al. (2015) observed parents' interactions with their children by providing them with a board game material and a book and found that math talk of parents had more diversity in the board game.

Second, findings showed that most of the parents perform activities that require mathematics skills with their children. This finding supports earlier research (LeFevre, Clarke \& Stringer, 2002; LeFevre et al., 2009; Pan, Yang, Li, Liu \& Liu, 2018) which reveals that parents provide their children with various experiences thanks to home math activities. The results of the study indicated that mothers and fathers with middle SES engage in math activities more frequently with their children in daily life than parents with low SES. This may be due to the parents with low SES insufficient awareness of the importance of home-based activities for their children to learn mathematics. Indeed, Cannon and Ginsburg (2008) found that parents who think their role is not important in children's mathematics learning engage in less activity with their children. These results are consistent with the findings that parents with low SES 
provide less mathematical support to their children than the others (Sonnenschein et al., 2016). Considering that the frequency of math activities with families at home contributes to children being more successful in mathematical skills (Huntsinger, Jose, Larson, Blasink Krieg \& Shaligram, 2000; LeFevre et al., 2010; Skwarchuk, 2009; Pan, Gauvain, Liu, \& Cheng, 2006), this finding suggests that children with low SES have a more disadvantaged home environment in terms of learning mathematics.

In this study, parents of both low and medium socioeconomic levels indicated that they frequently carried out activities related to counting and ordering events. On the other hand, they engaged in less formal activities such as measurement activities and working with a book related to math concepts. Parents' more focus on simple types of activities such as counting and ordering events rather than complex activities related to measurement and concept books in daily life may be due to their academic expectations. The academic skills families expect children to have affected the types of home math activities they practice (Skwarchuk, Sowinski, \& LeFevre, 2014). Del Rio, Susperreguy, Strasser and Salinas (2017) found that parents with high math expectations for their children carry out more advanced activities with them at home. Parents learning how to include other fields of mathematics in activities can contribute to providing a richer learning environment for children. The finding of the current study that parents mostly engage in activities related to counting and ordering events coincides with the results of previous studies (LeFevre et al., 2009; Blevins-Knabe \& MusunMiller, 1996) found that number activities and ordering the events experienced during the day were the most common math activities performed by families. Families carrying out activities requiring math skills with their children provide the opportunity for them to engage in mathematics (Purpura \& Reid, 2016). Therefore, the math materials offered to children at home and the math activities that parents engage with their children are seen as a source of children's mathematical input. The rich environment provided for children is decisive for the math skills that children will have (Gürgah Oğul \& Aktaş Arnas, 2020).

Moreover, the current study found that parent-children dyads with low and middle SES use expressions for many mathematical skills such as counting, classification, comparison, ordering, spatial perception, operations, measuring and one-to-one correspondence during daily conversations. This finding supports the research by Orçan Kaçan, Angın, \& Cerezci (2019), who found that parents use math concepts such as number, quantity, and time in their daily conversations with their children. Children's exposure to such conversations is beneficial for them to gain mathematical skills (LeFevre et al., 2009; Ramani \& Siegler, 2008). Ramani and Siegler (2008) found that children playing a game that includes numbers for even an hour with their families increased their math skills. The finding that both parents with low and middle SES have various math talks may indicate that parents have the potential to support children's math skills. In this regard, ways should be sought for parents to provide their children with more diverse math inputs in order to facilitate children's learning of math.

Last, in this study, the frequency of math talks of each parent-child dyad differs from each other. In all categories, parents with middle SES produced math talk more frequently than parents with low SES. Similarly, children with middle SES produced more math talks than did children with low SES in all categories except the one-to-one correspondence category. In fact, it is not surprising that parents with lower SES provided less math words to their children, as many studies (Hoff, 2013; Son \& Morrison, 2010) have found that parents with lower SES use much less words in their interaction with their children. A possible reason for this discrepancy is parents' beliefs about their own math skills and the importance of math in early years. Sonnenschein et al. (2012) found that parents who believe that doing math at 
young ages is important to provide more math activities to their children. Similarly, Missall et al. (2015) showed that parents who have positive beliefs about their own math skills engage in more math related interaction with their children.

\section{Conclusion \& implications}

The findings of this study support the idea that the home environment can provide the child with rich experiences in learning mathematical skills. Children have experiences that will help develop many mathematical skills in the home environment. During these experiences, making the parent-child interaction process efficient can pave the way for making meaningful contributions to the development of children.

The results obtained in the study have shed light on how parents could use the time spent with their children at home to the opportunity of mathematics learning. However, the current study has some limitations at the same time. The results of this study are limited to data from a small group. Further studies may conduct with larger sample to occur more general ideas about parental supports for the development of children's math skills. The study was limited to children's math talks with their parents in the home environment. The development of children's math skills can also be examined in the context of conversations with the teacher in the school context.

The study showed that the home learning environment provided by parents is a resource for children to develop math skills. In addition, SES is an important factor that should be taken into account in parental supports for children's math development. Parents should be aware of their roles and ensure more efficient interaction process. In the next step, ways should be found to support parents so that they can help their children learn more effectively.

Acknowledgments

We would like to thank the families and children for dedication of their time to participate this study.

\section{References}

Akıncı Coşkun, A., \& Tezel Şahin, F. (2019). Ev ortamında uygulanan sayı ve işlem eğitim programının ev ortamına etkisinin incelenmesi [Investigation of the effect of number and operation training program applied in home environment on home environment]. In Proceedings of the 2nd International Elementary Education Congress (pp. 897907). Muğla: Egiten Publication.

Altındağ Kumaş, Ö. (2020). Effectiveness of the big math for little kids program on the early mathematics skills of preschool children with a bilingual group. Participatory Educational Research, 7(2), 33-46. doi:10.17275/per.20.18.7.2

Aslan, D. (2020). "Is it a dairy product or food for breakfast?" Impact of preschool attendance on children's categorical abilities. Issues in Educational Research, 30(3), 809-827. Retrieved from http://www.iier.org.au/iier30/aslan.pdf

Aslan, D. (2013). The effects of socioeconomic status on children's categorization and crossclassification skills. International Journal of Social Sciences \& Education, 3(3), 644657. Retrieved from https://d1wqtxts1xzle7.cloudfront.net/31071653/Paper-11.pdf

Bailey, D. H., Siegler, R. S., \& Geary, D. C. (2014). Early predictors of middle school fraction knowledge. Developmental Science, 17(5), 775-785. doi:10.1111/desc.12155.

Bjorklund, D. F., Hubertz, M. J., \& Reubens, A. C. (2004). Young children's arithmetic strategies in social context: how parents contribute to children's strategy development 
while playing games. International Journal of Behavioral Development, 28(4), 347357. doi:10.1080/01650250444000027

Blevins-Knabe, B., \& Musun-Miller, L. (1996). Number use at home by children and their parents and its relationship to early mathematical performance. Early Development \& Parenting, 5, 35-45. doi:10.1002/(SICI)1099-0917(199603)5:1<35::AIDEDP113>3.0.CO;2-0

Burchinal, M., McCartney, K., Steinberg, L., Crosnoe, R., Friedman, S. L., McLoyd, V., \& Pianta, R. (2011). Examining the Black-White achievement gap among low-income children using the NICHD study of early child care and youth development. Child Development, 82, 1404-1420. doi:10.1111/j.1467-8624.2011.01620.x

Cannon, J., \& Ginsburg, H. P. (2008). "Doing the math": Maternal beliefs about early mathematics versus language learning. Early Education and Development, 19(2), 238260. doi:10.1080/10409280801963913

Compton, D., Love, T. P., Sell, J. (2012). Developing and assessing intercoder reliability in studies of group interaction. Sociological Methodology, 42, 348-364. doi:10.1177/0081175012444860.

Creswell, J. W. (2012). Educational research: Planning, conducting, and evaluating quantitative and qualitative research (4th ed.). Boston, MA: Pearson.

Crosnoe, R., Leventhal, T., Wirth, R. J., Pierce, K. M., \& Pianta, R. C. (2010). Family socioeconomic status and consistent environmental stimulation in early childhood. Child Development, 81(3), 972-987. doi:10.1111/j.1467-8624.2010.01446.x.

Çankaya, O., \& LeFevre, J. A. (2016). The home numeracy environment: What do crosscultural comparisons tell us about how to scaffold young children's mathematical skills? In B. Blevins-Knabe \& A. Austin (Eds.), Early childhood mathematics skill development in the home environment (pp. 87-104). Cham, Switzerland: Springer.

Çelik, M. (2015). Anasınıfına devam eden 60-72 aylık çocukların matematik gelişimlerinin bazı değişkenler açısından incelenmesi [Examining the mathematical development of 60-72 month-old children attending kindergarten in terms of some variables]. Dicle Üniversitesi Ziya Gökalp Ĕ̈itim Fakültesi Dergisi, 24, 1-18. Retrieved from https://dergipark.org.tr/en/pub/zgefd/issue/47937/606403

Davis-Kean, P. E. (2005). The influence of parent education and family income on child achievement: the indirect role of parental expectations and the home environment. Journal of Family Psychology, 19(2), 294. doi:10.1037/0893-3200.19.2.294

Dearing, E., Casey, B. M., Ganley, C. M., Tillinger, M., Laski, E., \& Montecillo, C. (2012). Young girls' arithmetic and spatial skills: The distal and proximal roles of family socioeconomics and home learning experiences. Early Childhood Research Quarterly, 27(3), 458-470. doi:10.1016/j.ecresq.2012.01.002

DeFlorio, L., \& Beliakoff, A. (2015). Socioeconomic status and preschoolers' mathematical knowledge: The contribution of home activities and parent beliefs. Early Education and Development, 26(3), 319-341. doi:10.1080/10409289.2015.968239

Del Río, M. F., Susperreguy, M. I., Strasser, K., \& Salinas, V. (2017). Distinct influences of mothers and fathers on kindergartners' numeracy performance: The role of math anxiety, home numeracy practices, and numeracy expectations. Early Education and Development, 28(8), 939-955. doi:10.1080/10409289.2017.1331662

Elliott, L., \& Bachman, H. J. (2018). SES disparities in early math abilities: The contributions of parents' math cognitions, practices to support math, and math talk. Developmental Review, 49, 1-15. doi:10.1016/j.dr.2018.08.001

Elliott, L., Braham, E. J., \& Libertus, M. E. (2017). Understanding sources of individual variability in parents' number talk with young children. Journal of Experimental Child Psychology, 159, 1-15. doi:10.1016/j.jecp.2017.01.011. 
Ertürk Kara, H. G. (2019). Okul öncesi dönemde çocuğa evde sunulan desteğin okuma yazmaya hazırlık ve matematik becerileri bağlamında incelenmesi. [Examining the support offered at home to preschool children in the context of literacy preparation and math skills]. Journal of Bayburt Education Faculty, 14(27), 87-105. doi:10.35675/befdergi.422261

Gunderson \& Levine (2011). Some types of parent number talk count more than others: Relations between parents' input and children's cardinal-number knowledge. Developmental Science, 14(5), 1021-1032. doi:10.1111/j.1467-7687.2011.01050.x

Gürgah Oğul, İ. \& Aktaş Arnas, Y. (2020). Role of mathematics activities and mothers' maths talk in predicting children's maths talk and early maths skills. European Early Childhood Education Research Journal, 29(4), 501-518. doi:10.1080/1350293X.2020.1858128.

Gürgah Oğul İ., Aslan, D. \& Aktaş Arnas, Y. (2018, June). A validity and reliability study of parents' participation in home math activities scale. Paper presented at 70th OMEP World Assembly and Conference, Prague, Czechia.

Hoff, E. (2013). Interpreting the early language trajectories of children from low-SES and language minority homes: Implications for closing achievement gaps. Developmental Psychology, 49, 4-14. doi:10.1037/a0027238

Huntsinger, C. S., Jose, P. E., Larson, S. L., Balsink Krieg, D., \& Shaligram, C. (2000). Mathematics, vocabulary, and reading development in Chinese American and European American children over the primary school years. Journal of Educational Psychology, 92(4), 745. doi:10.1037/0022-0663.92.4.745

İvrendi, A., \& Wakefield, A. (2009). Mothers' and Fathers' Participation in Mathematical Activities of Their Young Children. In H. Asutay \& E. Bayındır (Eds.), Education in Balkans Today-Proceedings of the 5th International Balkan Education and Science Congress (pp. 50-54). Edirne: Trakya University Publication.

Kağıtçıbaşı, Ç, \& Ataca, B. (2005). Value of children and family change: A three-decade portrait from Turkey. Applied Psychology: An International Review, 54(3), 317-337. Retrieved from https://iaap-journals.onlinelibrary.wiley.com/doi/pdf/10.1111/j.14640597.2005.00213.x

Karaman, S. \& İvrendi, A. (2015). Relationship among preschool period children's mathematical skills, socio-demographic characteristics and socio-dramatic play. Education and Science, 40(177), 313-326. doi:10.15390/EB.2015.3016

Klibanoff, R. S., Levine, S. C., Huttenlocher, J., Vasilyeva, M., \& Hedges, L. V. (2006). Preschool children's mathematical knowledge: The effect of teacher" math talk.". Developmental Psychology, 42(1), 59-69. doi:10.1037/0012-1649.42.1.59

LeFevre, J. A., Clarke, T., \& Stringer, A. P. (2002). Influences of language and parental involvement on the development of counting skills: Comparisons of French-and English-speaking Canadian children. Early Child Development and Care, 172(3), 283300. doi:10.1080/03004430212127

LeFevre, J. A., Skwarchuk, S. L., Smith-Chant, B. L., Fast, L., Kamawar, D., \& Bisanz, J. (2009). Home numeracy experiences and children's math performance in the early school years. Canadian Journal of Behavioural Science/Revue canadienne des sciences du comportement, 41(2), 55-66. doi:10.1037/a0014532

LeFevre, J., Polyzoi, E., Skwarchuk, S. L., Fast, L., \& Sowinski, C. (2010). Do home numeracy and literacy practices of Greek and Canadian parents predict the numeracy skills of kindergarten children? International Journal of Early Years Education, 18(1), 55-70. doi:10.1080/09669761003693926 
Levine, S. C., Ratliff, K. R., Huttenlocher, J., \& Cannon J. (2012). Early puzzle play: A predictor of preschoolers' spatial transformation skills. Developmental Psychology, 48(2), 530-542. doi:10.1037/a0025913

Levine, S. C., Suriyakham, L. W., Rowe, M. L., Huttenlocher, J., \& Gunderson, E. A. (2010). What counts in the development of young children's number knowledge? Developmental Psychology, 46(5), 1309-1319. doi:10.1037/a0019671

McCartney, K., \& Phillips, D. (Eds.). (2006). Blackwell handbook of early childhood development. Oxford, UK: Blackwell.

Melhuish, E. C., Phan, M. B., Sylva, K., Sammons, P., Siraj-Blatchford, I., \& Taggart, B. (2008). Effects of the home learning environment and preschool center experience upon literacy and numeracy development in early primary school. Journal of Social Issues, 64(1), 95-114. doi:10.1111/j.1540-4560.2008.00550.x

Missall, K., Robin L. H., Caskie, G. I. L., \& Repasky, P. (2015). Home numeracy environments of preschoolers: examining relations among mathematical activities, parent mathematical beliefs, and early mathematical skills. Early Education and Development, 26(3), 356-376. doi:10.1080/10409289.2015.968243

Mutaf Yıldiz, B., Sasanguie, D., De Smedt, B., \& Reynvoet, B. (2018). Frequency of home numeracy activities is differentially related to basic number processing and calculation skills in kindergartners. Frontiers in Psychology, 9, 340. doi:10.3389/fpsyg.2018.00340

Orçan Kaçan, M., Angın, D. E., \& Cerezci, B. (2019). Dinnertime math conversations between preschoolers and their parents. Journal of Education, Theory and Practical Research 5(3), 392-400. Retrieved https://dergipark.org.tr/en/pub/ekuad/issue/51148/666829

Orçan Kaçan, M., Yazıcı, E., \& Kandır, A. (2016). Ebeveynlerin Çocukların Matematik Eğitimine İlişkin Görüşlerinin İncelenmesi [Investigation of Parents' Views on Children's Mathematics Education]. Karadeniz Sosyal Bilimler Dergisi [Journal of Blacksea Social Sciences], 8(15), 301-319. Retrieved from https://dergipark.org.tr/en/pub/ksbd/issue/27237/286886

Pan, Y., Yang, Q., Li, Y., Liu, L., \& Liu, S. (2018). Effects of family socioeconomic status on home math activities in urban China: The role of parental beliefs. Children and Youth Services Review, 93, 60-68. doi:10.1016/j.childyouth.2018.07.006

Pan, Y., Gauvain, M., Liu, Z., \& Cheng, L. (2006). American and Chinese parental involvement in young children's mathematics learning. Cognitive Development, 21(1), 17-35. doi:10.1016/j.cogdev.2005.08.001

Patton, M. Q. (2002). Qualitative research and evaluation methods. Thousand Oaks, CA:Sage Publications.

Purpura, D. J., \& Reid, E. E. (2016). Mathematics and language: Individual and group differences in mathematical language skills in young children. Early Childhood Research Quarterly, 36, 259-268. doi:10.1016/j.ecresq.2015.12.020

Ramani, G. B., Rowe, M. L., Eason, S. H., \& Leech, K. A. (2015). Math talk during informal learning activities in Head Start families. Cognitive Development, 35, 15-33. doi:10.1016/j.cogdev.2014.11.002

Ramani, G. B., \& Siegler, R. S. (2008). Promoting broad and stable improvements in lowincome children's numerical knowledge through playing number board games. Child Development, 79(2), 375-394. doi:10.1111/j.1467-8624.2007.01131.x

Sarama, J., \& Clements, D. H. (2009). Early childhood mathematics education research: Learning trajectories for young children. New York, NY: Routledge. doi:10.4324/9780203883785 
Skwarchuk, S. L. (2009). How do parents support preschoolers' numeracy learning experiences at home?. Early Childhood Education Journal, 37(3), 189-197. doi:10.1007/s10643-009-0340-1

Skwarchuk, S. L., Sowinski, C., \& LeFevre, J. (2014). Formal and informal home learning activities in relation to children's early numeracy and literacy skills: The development of a home numeracy model. Journal of Experimental Child Psychology, 121, 63-84. doi:10.1016/j. jecp.2013.11.006.

Son, S. H., \& Morrison, F. J. (2010). The nature and impact of changes in home learning environment on development of language and academic skills in preschool children. Developmental Psychology, 46(5), 1103-1118. doi:10.1037/a0020065

Sonnenschein, S., Galindo, C., Metzger, S. R., Thompson, J. A., Huang, H. C., Lewis H. (2012). Parents' beliefs about children's math development and children's participation in math activities. Child Development Research, 2012, 1-13. doi:10.1155/2012/851657

Sonnenschein, S., Metzger, R., \& Thompson, J. A. (2016). Low-income parents' socialization of their preschoolers' early reading and math skills. Research in Human Development, 13(3), 207-224. doi:10.1080/15427609.2016.1194707

Susperreguy, M. I., \& Davis-Kean, P. E. (2016). Maternal math talk in the home and math skills in preschool children. Early Education and Development, 27(6), 841-857. doi:10.1080/10409289.2016.1148480

Susperreguy, M. I., Douglas, H., Xu, C., Molina-Rojas, N., \& LeFevre, J. A. (2020). Expanding the home numeracy model to Chilean children: Relations among parental expectations, attitudes, activities, and children's mathematical outcomes. Early Childhood Research Quarterly, 50, 16-28. doi:10.1016/j.ecresq.2018.06.010

Tudge, J. R., \& Doucet, F. (2004). Early mathematical experiences: Observing young Black and White children's everyday activities. Early Childhood Research Quarterly, 19(1), 21-39. doi:10.1016/j.ecresq.2004.01.007

Vandermaas-Peeler, M., Westerberg, L. \& Fleishman, H. (2019). Bringing known and new: Inquiry and intersubjectivity in parent-child interactions. Learning, Culture and Social Interaction, 21, 124-135. doi:10.1016/j.lcsi.2019.02.011

Vandermaas-Peeler, M., Boomgarden, E., Finn, L. \& Pittard, C. (2012). Parental support of numeracy during a cooking activity with four-year-olds. International Journal of Early Years Education, 20(1), 78-93. doi:10.1080/09669760.2012.663237

Vandermaas-Peeler, M., Nelson, J., Bumpass, C., \& Sassine, B. (2009). Numeracy-related exchanges in joint storybook reading and play. International Journal of Early Years Education, 17(1), 67-84. doi:10.1080/09669760802699910

Vygotsky, L. S. (1978). Mind in society: The development of higher psychological processes. Cambridge, MA: Harvard University Press.

Yin, R. K. (2014). Case study research: Design and methods (5th ed.). Thousand Oaks, CA: Sage Publications. 